\title{
PERANAN KOMISI PEMILIHAN UMUM KABUPATEN MERANGIN DALAM PEMUTAKHIRAN DATA PEMILIH
}

\author{
Agung Nugraha'), Nirmala Sari²) ,Gusila Ningsih"1) ,Mindi Syahri Ramdani1)
}

\author{
1)Mahasiswa Fakultas Hukum Universitas Muara Bungo \\ 2)Dosen Fakultas Hukum Universitas Muara Bungo \\ agungnugraha35@gmail.com,umb101016@gmail.com, \\ gusilanengsih05@gmail.com, mindimedina435@gmail.com
}

\section{RINGKASAN}

Pemilihan umum di Indonesia ada berbagai macam, salah satunya adalah pemilihan umum anggota Dewan Perwakilan Rakyat, Dewan Perwakilan Daerah, Dewan Perwakilan Rakyat Daerah (DPR, DPD, DPRD). Pemilihan DPR, DPD, DPRD secara langsung merupakan suatu pembelajaran demokratis bagi masyarakat, yang diharapkan dapat membentuk kesadaran masyarakat terkait pentingnya pemilihan DPR, DPD, DPRD, guna untuk mewujudkan pemerintahan yang demokratis berdasarkan Pancasila dan Undang-Undang Dasar Republik Indonesia Tahun 1945. Dalam pelaksanaannyaPemilihan Umum Anggota DPR, DPD, DPRD secara langsung, umum, bebas, rahasia, jujur, dan adil dapat terwujud apabila penyelengara pemilihan yang mempenyai integritas, profesional, dan akuntabilitas. Artikel ini dilatar belakangi adanya permasalahan yang kerap terjadi dalam pemilihan umum yaitu dalam penyusunan daftar pemilih yang buruk.Kekeliruan pendataan pemilih,jumlah pemilih yang simpang siurdan munculnya, adanya pemilih ganda, pemilih yang belum terdata merupakan persoalan dalam penyusunan daftar pemilih pada pemilihan umum anggota DPR, DPD, DPRD tahun 2014. Dalam hal ini Pemerintah harus mempercepat regulasi data kependudukan, sehingga carut marut DPT dalam penyelenggaraan pemilu dapat di atasi, hal ini juga bermanfaat bagi terjaminnya hak konstitusional seluruh warga Negara dalam menyalurkan aspirasi

Kata Kunci: Peranan, KPU, Pemutakhiran Data

\section{PENDAHULUAN}

Pemilihan Umum merupakan salah satu perwujudan dalam menyalurkan aspirasi warga Negara Indonesia, karena PemilihanUmum begitu sangat mendasar dalam kehidupan ketatanegaraan Indonesia, oleh sebab itu Pemilihan Umum merupakan salah satu sarana utama untuk menegakkan tatanan demokrasi yang berkedaulatan rakyat, yang berfungsi sebagai alat menyehatkan dan menyempurnakan demokrasi. ${ }^{1}$ Sesuai dengan amanat dari Undang-Undang Dasar Negara Republik Indonesia Tahun 1945

${ }^{1}$ Sodikin, Hukum Pemilu, Pemilu Sebagai Praktek Ketatanegaraan, Gramata publishing, Bekasi hal. 3. dalam Pasal l ayat (2) yang menyatakan kedaulatan di tangan rakyat dan dilaksanakan menurut Undang-Undang Dasar, Pasal ini menunjukan bahwa kedaulatan rakyat perlu dilaksanakan melalui Pemilihan Umum. Dalam penyelenggaraannya,penyelenggara

Pemilihan Umum memiliki posisi strategis berkaitan dengan penyelenggaraan pemilihan umum, dalam perjalanan politik di Indonesia, penyelenggara pemilihan umum mempunyai dinamika sendiri. ${ }^{2}$

Pemilihan umum di Indonesia ada berbagai macam, salah satunya adalah pemilihan umum anggota Dewan 
Perwakilan Rakyat, Dewan Perwakilan Daerah, Dewan Perwakilan Rakyat Daerah (DPR, DPD, DPRD). Pemilihan DPR, DPD, DPRD secara langsung merupakan suatu pembelajaran demokratis bagi masyarakat, yang diharapkan dapat membentuk kesadaran masyarakat terkait pentingnya pemilihan DPR, DPD, DPRD, guna untuk mewujudkan pemerintahan yang demokratis berdasarkan Pancasila dan Undang-Undang Dasar Republik Indonesia Tahun $1945 . \quad$ Dalam pelaksanaannyaPemilihan Umum Anggota DPR, DPD, DPRD secara langsung, umum, bebas, rahasia, jujur, dan adil dapat terwujud apabila penyelengara pemilihan yang mempenyai integritas, profesional, dan akuntabilitas.

Indonesia merupakan negara yang sangat luas dan merupakan negara dengan penduduk terbanyak setelah China, India dan Amerika.Luas wilayah dan penduduk yang menyebar diseluruh pelosok menimbulkan masalah yang komplek dalam penyelengaraan pemilihan umum, sehingga menuntut penyelenggaraan pemilihan umum yang profesional dan memiliki kredibilitas yang dapat dipertanggung jawabkan.

Menurut Rozali AbdullahPemilihan Umum yang berkualitas dapat dilihat dari dua sisi, yaitu sisi proses dan hasilnya:

Dari sisi proses, pemilihan umum dapat dikatakan proses apabila pemilihan umum berlansung secara demokratis jujur, adil, tertib, dan lancar. Dari sisi hasil, pemilihan umum dapat di katakan berkualitas, apabila

pemilihan umum dapat menghasilkan wakil-wakil rakyat dan pemimpin negara, yang mampu meningkatkan kesejahteraan masyarakat,serta mampu meningkatkan harkat dan martabat bangsa dan negara di mata masyarakat internasional. ${ }^{3}$

Dalam penyelenggaraannya Komisi Pemilihan Umum telah di atur didalam

\footnotetext{
${ }^{3}$ Rozali Abdullah, Sistem Pemilu Legislatif dan Pemilu Presiden Ditinjau dari Sudut Demokras, Jurnal Konstitusi 2009 Volume II No. 1 hal.12.
}

Undang-Undang Dasar Republik Indonesia Tahun 1945 Pasal 22E ayat (5)yang menyatakan "bahwa Pemilihan Umum diselenggarakan oleh Komisi Pemilihan Umum yang bersifat nasional tetap dan mandiri". Amanat kontitusi tersebut untuk memenuhi tuntutan perkembangan kehidupan politik,dinamika masyarakat, dan perkembangan demokrasi yang sejalan dengan pertumbuhan kehidupan berbangsa dan bernegara.

Pemilihan umum anggota DPR, DPD, DPRD dalam konsiderans Undang-Undang Nomor 8 Tahun 2012 merupakan sarana perwujudan kedaulatan rakyat untuk menghasilkan wakil rakyat yang aspiratif, dan bertanggung jawab berdasarkan Pancasila dan Undang-Undang Dasar Negara Republik Indonesia Tahun 1945. Untuk menghasilkan pemilihan umum yang berkualitas lembaga negara yang berwenang dalam penyelenggaraannya di daerah di jelaskan pada Undang-Undang Nomor 8 Tahun 2012 pada Pasal 1 ayat (8) yang menyatakan "Bahwa Komisi Pemilihan Umum Kabupaten/Kota selanjutnya disingkat KPU Kabupaten/ Kota adalah penyelenggara pemilu yang bertugas melaksanakan pemilu di Kabupaten/Kota". Melalui pemilihan langsung akanmembuat keseimbangan dengan suprastruktur politik mengingat pemilihan langsung oleh rakyat dapat menentukan jalannya pemerintahan dengan memilih wakil rakyat yang di kehendaki secara bebas dan rahasia sesuai dengan prinsip jujur dan adil.

Sebagai penyelenggara pemilihan anggota DPR, DPD, DPRD Komisi Pemilihan Umum Daerah perlu menjalankan tugasnya agar pemilihan umum Anggota DPR,DPD,DPRD berjalan dengan baik, ada beberapa tugas penyelenggaraan pemilihan umum Anggota DPR, DPD, DPRD berdasarkan Pasal 8 ayat (1) UndangUndang Nomor 15Tahun 2011 antara lain sebagai berikut :

a. Menjabarkan program dan melaksanakan anggaran serta menetapkan jadwal di kabupaten/kota;

b. Melaksanakan semua tahapan penyelenggaraan di kabupaten/kota berdasarkan 
ketentuan

peraturan

perundang-undangan;

c. Membentuk PPK, PPS, dan KPPS dalam wilayah kerjanya;

d. Mengoordinasikan dan mengendalikan tahapan penyelenggaraan oleh PPK, PPS, dan KPPS dalam wilayah kerjanya;

e. Menyampaikan daftar pemilih kepada KPU Provinsi;

f. Memutakhirkan data pemilih berdasarkan data kependudukan yang disiapkan dan diserahkan oleh Pemerintah dengan memperhatikan data Pemilu dan/atau pemilihan gubernur, bupati, dan walikota terakhir dan menetapkannya sebagai daftar pemilih;

g. Menetapkan dan mengumumkan hasil rekapitulasi penghitungan suara Pemilu Anggota Dewan Perwakilan Rakyat Daerah Kabupaten/Kota berdasarkan hasil rekapitulasi penghitungan suara di PPK dengan membuat berita acara rekapitulasi suara dan sertifikat rekapitulasi suara;

h. Melakukan dan mengumumkan rekapitulasi hasil penghitungan suara Pemilu Anggota Dewan Perwakilan Rakyat, Anggota Dewan Perwakilan Daerah, dan Anggota Dewan Perwakilan Rakyat Daerah Provinsi di kabupaten/kota yang bersangkutan berdasarkan berita acara hasil rekapitulasi penghitungan suara di PPK;

i. Membuat berita acara penghitungan suara dan sertifikat penghitungan suara serta wajib menyerahkannya kepada saksi peserta Pemilu, Panwaslu Kabupaten/Kota, dan KPU Provinsi;

j. Menerbitkan keputusan KPU Kabupaten/Kota untuk mengesahkan hasil Pemilu Anggota Dewan Perwakilan Rakyat Daerah Kabupaten/Kota dan mengumumkannya; k. Mengumumkan calon anggota Dewan Perwakilan Rakyat Daerah Kabupaten/Kota terpilih sesuai dengan alokasi jumlah kursi setiap daerah pemilihan di kabupaten/kota yang bersangkutan dan membuat berita acaranya;

l. Menindaklanjuti dengan segera temuan dan laporan yang disampaikan oleh Panwaslu Kabupaten/Kota;

m. Mengenakan sanksi administratif dan/atau menonaktifkan sementara anggota PPK, anggota PPS, sekretaris KPU Kabupaten/Kota, dan pegawai sekretariat KPU Kabupaten/Kota yang terbukti melakukan tindakan yang mengakibatkan terganggunya tahapan penyelenggaraan Pemilu berdasarkan rekomendasi Panwaslu Kabupaten/Kota dan/atau ketentuan peraturan perundang-undangan;

n. Menyelenggarakan sosialisasi penyelenggaraan Pemilu dan/atau yang berkaitan dengan tugas dan wewenang KPU Kabupaten/Kota kepada masyarakat;

o. Melakukan evaluasi dan membuat laporan setiap tahapan penyelenggaraan Pemilu; dan

p. Melaksanakan tugas dan wewenang lain yang diberikan oleh KPU, KPU Provinsi, dan/atau peraturan perundangundangan.

Dari tugas KPU yang tertera diatas KPU Kabupaten Merangin masih mengalami masalahdalam tahapan pemutakhirkan daftar pemilih,hal tersebut membuat KPUKabupaten Merangin mengalami masalah serius dalam pemutakhiran daftar pemilih karena adanya muncul pemilih ganda,penduduk yang belum terdata kedalam daftar pemilih tetap, yang membuat KPU Kabupaten Merangin dipertanyakan perannya dalam 
pemutakhirkan daftar pemilih.Pada dasarnya pemilihan umum anggota DPR,DPD,DPRD akan berjalan dengan sangat baik dan tanpa masalah apabila penyusunan daftar pemilih berjalan dengan baik, jika permasalahan pemutakhirkan daftar pemilih tidak ada masalah tentu pemilihan umum akan berjalan lebih lancar tanpa adanya masalah, karena KPU selaku penyelenggara pemilihan umum telah memberikan kesempatan kepada mayarakat untuk memilih wakilnya didalam pemerintahan. Ketentuan mengenai Pemutakhiran daftar pemilih oleh KPU dalam pemilihan anggota DPR, DPD, DPRD diatur didalam Undang-Undang Nomor 15 Tahun 2011 tentang Penyelengaraan Pemilihan Umum.

Artikel ini dilatar belakangi adanya permasalahan yang kerap terjadi dalam pemilihan umum yaitu dalam penyusunan daftar pemilih yang buruk.Kekeliruan pendataan pemilih,jumlah pemilih yang simpang siurdan munculnya, adanya pemilih ganda, pemilih yang belum terdata merupakan persoalan dalam penyusunan daftar pemilih pada pemilihan umum anggota DPR, DPD, DPRD tahun 2014. Berdasarkan wanwancara bersama Adam Kurniawan selaku teknisi KPU Kabupaten Merangin, mengatakan:

Permasalahan penysusunan daftar pemilih awalnya terjadi karena adanya kelalaian pada masyarakat pendatang yang tidak mendaftarkan diri ke Kantor Catatan Sipil sebagai masyarakat Kabupaten Merangin yang sah, sehingga karena mereka tidak mendaftarkan diri mereka secara tidak langsung mereka juga tidak diakui kependudukan sebagai penduduk di Kabupaten Merangin, dan pada saat dimulainya petugas KPUD dalam pemutakhiran daftar pemilih, ternyata masih ada pemilih yang belum masuk kedalam Daftar Pemilih Tetap dan ketika ditemuimereka hanya memegang keterangan domisili dari Kepala Desa mereka masing-masing seperti yang terjadi di dsesa tuo, oleh karena itu untuk melakukan pendataan ulang KPU Kabupaten Merangin turun kelapangan untuk mendata kembali, akan tetapi dengan waktu yang sangat singkat dan kondisi geografis yang sangat jauh serta sulit di tempuh dan untuk mendata begitu banyaknya warga yang belum terdata, sangat menyulitkan bagianggota KPU Kabupaten Merangin untuk menyelesaikan keseluruhan masalah pemutakhiran pemilih. ${ }^{4}$

Selain itu Berdasarkan rekapitulasi penghitungan suara Kabupaten Merangin jumlah pemilih yang bermasalah dan yang sangat mencolok terjadi di Kecamatan Lembah Masurai berdasarkan data yang diberikan olehKPU kabupaten merangin pemilih yang masuk dalam Daftar Pemilih Khusus yaitu sebanyak 1.048 pemilih dan Kecamatan Bangko dengan pemilih yang masuk Daftar Pemilih Khusus 920 pemilih.

\section{PEMBAHASAN}

KPU Kabupaten Merangin telah melakukan berbagai cara untuk menyelesaikan masalah dalam pemutakhiran mata pilih ini di mana mereka memulai mendata kembali masyarakat yang belum terdaftar kedala Daftar Pemilih Tetap (DPT) dengan mendatangi tempat yang mengalami permasalahan penyusunan daftar mata pilih, akan tetapi dalam penyusunan tersebut KPU Kabupaten Merangin mengalami masalahdengan waktu yang sangat singkat dengan daerah Kabupaten Merangin yang cukup luas sehingga tidak semuanya bisa penyusunan DPT terselesaikan seutuhnya, sehingga pada saat pemilihan berlangsung pemilih yang terdata kedalam DPT sebanyak 255.515 dari yang berawal DPT 253.393 pemilih. Akan tetapi pemilih yang tidak masuk kedalam DPT KPUmemasukan mereka kedalam Daftar Pemilih Khusus.Meskipun pada saat penyelenggaraannya pemilihan umum Anggota DPR, DPD, DPRD di Kabupaten Merangin berjalan dengan lancar, Komisi Pemilihan UmumKabupaten

\footnotetext{
${ }^{4}$ Wawancara Adam Kurniawan, Teknisi
} KPU Kabupaten Merangin, tanggal 17 Maret, Jam $10.15 \mathrm{Wib}$. 
Merangin masih memiliki masalah khusus dalam hal penyusunan daftar pemilih. ${ }^{5}$

Dengan demikian pemutakhiran daftar pemilih untuk Pemilihan anggota DPR, DPD, DPRD di Kabupaten Meranginmerupakan tugas pokok dari KPU Kabupaten Merangin hal ini di atur dalam paragraph 2 (dua) ayat (1) huruf (f).Dalam hal ini KPU Kabupaten Merangin memegang peran penting dalammewujudkan pemilihan umum yang berkualitas sesuai dengan amat Undang- Undang Dasar Negara Republik Indionesia Tahum 1945.

Peranan KPU Kabupaten Merangin dalam Pemutakhiran data Pemilih tahun 2014 sangat sentral sekali. Hal ini di karenakan bahwa Pemilihan Umum Anggota DPR, DPD, DPRD merupakan perwujudan demokrasi yang dilakukan secara langsung oleh rakyat sebagaimana diatur di dalam Undang - Undang Negara Republik Indonesia Tahun 1945, dalam penyelenggaraannya Pemilihan Umum di atur di dalam Undang- Undang Nomor 15 Tahun 2011 Tentang Penyelenggaraan Pemilu. Dalam pelaksanaan pemilihan Anggota DPR, DPD, dan DPRD KPU Kabupaten Merangin mempunyai tugas dan kewajiban untuk menyelenggarakan Pemilihan Umum tersebut terutama dalam pemutakhiran daftar pemilih.

Pengaturan Tugas dan wewenang Komisi Pemilihan Umum tercantum di dalam Undang - Undang Nomor 15 Tahun 2011 Tentang Penyelenggaraan Pemilu.Tugas dan Wewenang tersebut diatur lebih rinci di dalam Peraturan Komisi Pemilihan UmumNomor 9 Tahun 2013 Tentang Penyusunan Daftar Pemilih Untuk Anggota DPR, DPD, DPRD. Berdasarkan Peraturan Komisi Pemilihan Umum Nomor 9 Tahun 2013 tentang tentang Penyusunan Daftar Pemilih untuk Pemilihan Umum Anggota Dewan Perwakilan Rakyat, Dewan Perwakilan Daerah dan Dewan Perwakilan Rakyat Daerah. Data Pemilih Sementara (DPS)

${ }^{5}$ Komisi Pemilihan Umum Kabupaten Merangin, Rekapitulasi Penghitungan Suara Pemilihan Umum Anggota DPR,DPD,DPRD Tahun 2014. Bangko, 2014.
Dalam Penyusunan DPS KPU Kabupaten Merangin menurunkan Panitia Pendaftar Pemilih (Pantarlih) untuk melakukan verifikasi faktual terhadap data Pemilih berbasis TPS selama 2 (dua) Bulan sejak perlengkapan pemutakhiran data.Pantarlih dalam verifikasi faktual melakukan:

a.Mencatat pada form A.A. KPU yakni:

1. Pemilih yang telah memenuhi syarat namun belum terdaftar.

2. WNI yang memenuhi syarat namun tidak terdaftar karena tidak ada identitas kependudukan.

3. Pemilih yang berada di domisili wilayah kerja Pantarlih namun memiliki identitas kependudukan wilayah lain dan kemudian pemilih tersebut menyatakan akan memilih di wilayah kerja pantarlih tersebut bukan pada domisili yang tertera pada identitas kependudukan.

b. Memperbaiki data pemilih jika ada kesalahan.

c. Mencoret Pemilih :

1. meninggal

2. Pindah domisili

3. Belum genap berumur 17 tahun dan/atau belum kawin

4. berubah status menjadi anggota TNI/Polri

5. yang telah dipastikan tidak ada keberadaannya.

Pemilu satu ke Pemilu lainnya Pemutakhiran Data pemilih menjadi salah satu isu yang terus menjadi sorotan.Ketidak akuratan Data Pemilih disinyalir merupakan salah satu alasan mengapa Daftar Pemilih menjadi sorotan. Perkembangan Pemutakhiran Daftar Pemilih tidak akan lepas dari regulasi yang menjadi dasar pegangan penyelenggara Pemilu dalam melakukan Pemutakhiran Data Pemilih. 
Kendala - kendala yang diahapi KPU Kabupaten Merangin dalam pemutakhiran data pemilih dalam pemilihan anggota DPR, DPD, DPRD tahun 2014 antara lain :

\section{Masih Terdaftarnya Pemilih Ganda}

Masih terdaftarnya pemilih ganda yang tidak memenuhi persyaratan dalam DPT dan juga rentan dilakukannya manipulasi seperti 1 orang menggunakan hak pilih lebih dari 1 kali.Terdaftarnya pemilih ganda tentu akan merusak citra demokrasi di Indonesia, ini sering sekali terjadi dalam pemilihan umum :

Pihak KPU sudah melakukan tugas nya dengan terjun ke langsung ke kecamatan yang terkait untuk melakukan vertifikasi ulang sehingga adanya keterbukaan yang kerja kami terhadap masyarakat sebagai pemilih, jika dilokasi ditemukan demikian kami dari pihak KPU langsung mencoret nama pemilihtersebut. ${ }^{6}$

\section{Adanya Pemilih Fiktif}

Pemilih fiktif sering kali di temukan dalam pemilihan umum, hal ini akan merusak citra pemilihan umum yang berkualitas, demokratis serta jujur dan adil sesuai dengan Undang Undang Nomor 15 Tahun 2011 Tentang Penyelenggaraan Pemilu dan Pasal 22E Undang - Undang Dasar Negara Republik Indonesia Tahun 1945 maka dari itu.

KPU melakukan vertifikasi ulang per kecamatan dan mendata ulang pemilih dan jika di temukan pemilih fiktif tersebut maka langsung akan dihapus, seperti yang terjadi waktu itu di kecamatan Lembah masuraiKami nemukan hal tersebut dan langsung kami hapus pemilih tersebut. Akan tetapi dengan waktu yang semakin mendekati waktu pemilihan dan daerah kabupaten merangin ini sangat luas dan berbukit sehingga sangat memakan

\footnotetext{
${ }^{6}$ Wawancara bersama Iron Sahroni, ketua Komisi Pemilihan Umum Kabupaten Merangin 4 oktober 2015.
}

waktu untuk menempuhnya maka kami kesulitan dan tidak bisa kami melakukan secara menyeluruh. ${ }^{7}$

\section{Petugas Tidak Melakukan Tugasa Secara Maksimal.}

Kendala lainyang dapat menghambat pemutakhiran data Pemilih adalah Sumber Daya Manusia itu sendiri. Sumber daya manusia yang dibutuhkan dalam Pemutakhiran Data Pemilih harus banyak jumlahnya agar lebih teliti dan jeli, tidak terlalu luas cakupan wilayah kerjanya dan juga memiliki kemampuan dalam mengaplikasikan peraturan ataupun prosedur pemutakhiran Data Pemilih.

Keberadaan Panita

Pemutakhiran Data Pemilih (PPDP) ataupun Pantarlih merupakan ujung tombak dari Pemutakhiran Data Pemilih. Oleh karena itu, untuk mendapatkan Data Pemilih yang akurat maka PPDP ataupun Pantarlih harus diisi oleh orang orang yang teliti, jeli, dan gigih dalam melakukan pemutakhiran data pemilih. Selain itu mereka juga diharapkan mampu mengaplikasikan peraturan ataupun prosedur pemutakhiran data Pemilih dengan baik dan benar. Sehingga pada akhirnya akan menentukan kualitas Data Pemilih yang dihasilkan.

Dalam KPU Kabupaten Merangin kita sudah memiliki sumber daya manusia yang berkualitas tetapi kita masih agak kesulitan mendata keseluruan pemilih yang di kabupaten merangin dengan baik, di tambah lagi jumlah pemilih sangat banyak dan cakupan wilayah perkecamatan itu sangat luas jadi susah juga mengandalkan petugas KPU ini. Dalam pemutakhiran data itu tentunya KPU tidak bekerja sendiri dalam peosesnya

\footnotetext{
${ }^{7}$ Wawancara bersama Adam Kurniawan , anggota Komisi Pemilihan Umum Kabupaten Merangin 13 oktober 2015.
} 
pendataan pemilih dan Pemutakhiran data pemilih KPU dibantu oleh PPK, PPS, dan Pantarlih. ${ }^{8}$

Selain itu panwaslu sebagai petugas panitia yang mengawasi jalannya pemilu juga menjadi kunci suksesnya penyelenggaraan pemilu guna menyampaikan laporan kepada Panwaslu Kabupaten/Kota berkaitan dengan adanya dugaan tindakan yang mengakibatkan terganggunya penyelenggaraan tahapan Pemilu di tingkat Kecamatan. Dalam hal ini tentu tugas Panwaslu untuk mengawasi pemilu sangat penting hal iitu disampaikan oleh Ketua Panwaslu Kabupaten Merangin:

Untuk laporan salah yang terjadi kami akan cepat menindaki masalah dan segera melaporkan masalah dalam pemilu dengan cepat akan tetapi dalam pengawan pemilu ini juga ada Faktor penghambat kinerja Panwaslu yang berhubungan dengan masalah Sumber Daya Manusia yang pertama keanggotaan Panwaslu itu sangat sedikit sekali semuanya di atur dalam Undang - Undang Nomor 15 tahun 2011 Tentang Penyelenggara Pemilu di dalam Pasal 72 ayat (2), disini dijelaskan bahwa jumlah anggota Panwaslu sebanyak 3 (tiga) orang baik Panwaslu Kabupaten maupun Panwaslu Kecamatan. Sedangkan dalam hal ini yang akan diawasi itu kabupaten Merangin yang kita ketahui sangat luas dan berbukit ini juga yang terdiri dari 24 kecamatan.Perbandingan sangat signifikan sekali antara pihak Panwaslu dalam hal ini yang melakukan fungsi atau peran pengawasan pemilu dengan jumlah Daftar Pemilih Tetap

${ }^{8}$ Wawancara bersama Iron sahroni S.Pdi, ketua Komisi Pemilihan Umum Kabupaten Merangin 4 oktober 2015. pada tahun 2014 yang sebanyak255.515pemilihyang tersebar di851 TPS untuk 24 Kecamatan di kabupaten merangin yang akan menjadi objek yang diawasi, tentu saja dapat dipastikan bahwa pengawasan pemilu menjadi tidak efektif.Kedua, Pendidikan anggota Panwaslu dalam hal ini Panwaslu Kecamatan kurang memadai dalam hal menjalankan tugas dan kewenangannya.Masalah pendidikan atau kapasitas dapat dilihat dengan banyaknya anggota Panwaslu Kecamatan tidak memahami tugas dan wewenangnya, bahkan di antara anggota Panwaslu Kecamatan tidak berkompeten dalam melakukan pengawasan Pemilihan DPR, DPD, DPRD. Maka dari itu kebanyakan anggota Panwaslu Kecamatan kurang memahami regulasi yang ada yang berhubungan dengan pengawasan Pemilihan Anggota DPR, DPD, DPRD. 9

\section{Kurangnya Peran Aktif Warga Dalam Memastikan Diri Terdaftar Sebagai Pemilih.}

Kendala dan hambatan lainnya adalah peran aktif warga sangat di perlukan agar pemutakhiran data pemilih, ini tidak terjadi masalah dengan cara melaporkan bahwa masih ada pemilih di lingkungan mereka tidak masuk dalam daftar pemilih sehingga memudahkan panita terkait untuk memperbaiki daftar pemilih.

Jika dilihat faktanya dilapangan masyarakat banyak yang tidak terlalu peduli dengan daftar pemilih ini, hal ini sering terjadi di tiap kecamatan, panitia sudah menempel daftar pemilih tetapi pemilih tidak mau memastikan

\footnotetext{
${ }^{9}$ Wawancara bersama Bapak Drs. Mukti Z SebagaiKetua Panwaslu Kabupaten Merangin tanggal 14 November 2015.
} 
bahwa adanya nama mereka di sana, nah jika waktu dekat pemilihan mereka tidak masuk baru mereka protes, sehingga pada pemilihan sering terjadi perselisihan antara panita terkait dengan mastarakat. ${ }^{10}$

Hal yang sama juga diungkapkan oleh Kepala Desa dan Masyarakat desa di Kecamatan Lembah Masurai itu sendiri sebagai berikut:

Benar adanya seperti itu warga desa disini memang tidak sempat untuk melihat daftar pemilih yang ditempelkan oleh petugas, karena warga sudah percaya dengan kerja keras dari petugas dan ditambah lagi kebanyakan dari warga disini adalah petani jadi kebanyakan di ladang dari pada dirumah jadi tidak sempat untuk melihat. ${ }^{11}$

Saya juga setuju tidak semua warga disini sempat untuk melihat daftar pemilih yang di tempelkan karena alasan yang sama yaitu mereka sibuk ke ladang mereka untuk bertani tetapi tidak banyak juga dari mereka yang melihat daftar pemilih tersebut. 12

Tapi tidak semuanya tidak ikut memilih gara - gara tidak tercantum di dalam daftar pemilih, untuk pemilih yang muda kebanyakan tidak ikut memilih hal itu karena mereka sedang kuliah diluar daerah jadi mereka yang tidak memilih karena faktor libur Pemilu itu

\footnotetext{
${ }^{10}$ Wawanwara bersama Bapak Hendri Putra S.Sos selaku Camat di Kecamatan Lembah Masurai 17 November 2015

${ }^{11}$ Wawancara bersama Bapak Sarifudin selaku Kepala Desa Kecamatan Lembah Masurai 25 Oktober 2015.

${ }^{12}$ Wawancara bersama Bapak Muhamad Diargo S.Pd Masyarakat Kecamatan Lembah Masurai 25 Oktober 2015.
}

sebentar jadi banyak yg dak milih. ${ }^{13}$

Berbeda dengan Kecamatan Lembah Masurai yang kebanyakan masyarakatnya bertani, Kecamatan Bangko juga banyak masyarakatnya yang tidak memilih hal ini disampaikan oleh Fauziah selaku Camat Bangko sebagai berikut:

Dalam pelaksanaan pemilu Anggota DPR, DPD, DPRD yang terjadi pada tahun 2014 Kecamatan Bangko tentunya sebagai salah satu daerah di kabupaten Merangin sudah terjadi cukup baik hanya saja masih banyak nya kurang kesadaran masyarakat untuk ikut memilih tentu jadi pekerjaan yang sulit ditambah lagi sebagian besar masyarakat di Kecamatan Bangko Kabupaten Merangin ini banyak juga pemilih baru, dan ini bukan hanya terjadi di Kecamatan Bangko ini di seluruh Kecamatan di Kabupaten Merangin pemuda ini sebagai pemilih banyak yang tidak ikut memilih Karena pendidikan di luar daerah maka pemilih dari kalangan pemuda di disini banyak yang tidak ikut memilih di pemilihan Umum Anggota DPR, DPD, DPRD pada Tahun 2014. ${ }^{14}$

Hal yang serupa disampaikan olehMustakim selaku Lurah Pematang Kandis dan masyarakat kelurahan pematang kandis yang mengatakan :

Untuk dikota Bangko khususnya Kelurahan Pematang Kandis saat Pemilihan Anggota DPR, DPD, DPRD itu dilakukan saya melihat banyak juga yang tidak memilih, dan kebanyakan yang

\footnotetext{
${ }^{13}$ Wawancara bersama Bapak Anggi Prayogi Masyarakat Kecamatan Lembah Masurai 28 Oktober 2015.

${ }^{14}$ Wawancara bersama IbuFauziah S.Pd. selaku Camat Bangko 17 November 2016.
} 
tidak memilih disini para remaja, kenapa bisa remaja ini kebanyakan para remaja di kota Bangko khususnya di Kelurahan Pematang Kandis ini rata - rata sedang menjalani pendidikan di luar daerah, hal ini yang membuat banyak remajaini tidak memilih dalam Pemilu Anggota DPR, DPD, DPRDtahun $2014 .{ }^{15}$

Benar sekali banyak sekali pemuda disini yang tidak ikut memilih dalam pemlu anggota DPR, DPD, DPRD tahun 2014 lalu, saya sendiri sebagai pemuda dan tentunya saya juga seorang mahasiswa di salah satu Universitas Swasta di Sumatra Barat secara pribadi mengakui tidak mengikuti pemilu itu, karena saya juga mersa tidak dirugikan jika tidak memilih pada pemilu anggota DPR, DPD, DPRD, ditambah lagi tempat saya menuntut ilmu itu diluar Provinsi jambi ini dan libur untuk pemilu hanya satu hari jadi untuk pulang memilih itu saya tidak mau dan saya lebih memilih untuk menetap di Sumatra Barat saat itu. ${ }^{16}$

Dari hasil wawancara diatas dapat disimpulkan bahwa KPU Kabupaten Merangin dalam pemutakhiran data tidak bekerja sendiri, KPU Kabupaten Merangin dalam pemutakhiran data tersebut dibantu oleh PPK, PPS, Pantarlih, dan keikutan serta masyarakat dalam memberikan masukan kepada KPU Kabupaten Merangin untuk pemutakhiran data sangat berpengaruh dalam pemutakhiran

${ }^{15}$ Wawancara bersama Bapak Mustakim S.Pdi. selaku Lurah Pematang kandis 19 November 2015

${ }^{16}$ Wawancara bersama Bobi Maika Putra selaku masyarakat kecamatan bangko 20 september 2015 tersebut sehingga hal itu dapat mempengaruhi kesuksesan pelaksanaan Pemilihan Anggota DPR, DPD, DPRD tahun 2014.

Kemudian untuk menyukseskan Pemilihan Umum yang selanjutnya KPU Kabupaten Merangin diharapkan Perlu melibatkan semua pihak untuk terjaminya kelancaran saat melakukan pemutakhiran data pemilih, serta sebaiknya KPU perlu memiliki sistem pemutakhiran daftar pemilih yang lebih akurat dalam membaca Pemilih ganda atau tidak memenuhi syarat sebagai Pemilih, sehingga seluruh masyarakat dapat menyalurkan aspirasinya dan terpenuhilah hak konstitusional dalam memberikan aspirasinya.

\section{Kesimpulan}

Berdasarkan uraian diatas pada bab bab sebelumnya yang berkaitan dengan pokok permasalahan, maka dapat disimpulkan sebagai berikut:

1. KPU Kabupaten Merangin telah melaksanakan tugasnya dalam hal pemutakhirkan data pemilih, hal itu dapat dilihat berdasarkan proses pemutakhiran data dimulai dari penyerahan data oleh pemerintah dalam hal ini KPU meminta data dari Departemen Dalam Negeri, kemudian data tersebut di singkronisasi oleh KPU Kabupaten Merangin bersama dengan Dinas Dukcapil untuk dijadikannya DP4, data tersebut kemudian dijadikan acuan untuk pembentukan DPS, DPSHP sampai pemutakhiran DPT dan diserahkan data tersebut kepada PPK dan jajarannya untuk didistribusikan kepada tiap tiap TPS.

2. Kinerja KPU Kabupaten Merangin dalam Pemutakhiran data masih jauh dari kata sempura hal ini dapat dilihat dari banyaknya jumlah pemilih 
yang mengeluh karena tidak masuk kedalam DPT, masih adanya pemilih fiktif, dan masih adanya pemilih ganda Kurangnya peran aktif warga dalam memastikan diri terdaftar sebagai pemilih, petugas tidak melakukan tugasa secara maksimal. Sehingga terjadinya konflik dalam pemilihan umum.

\section{A. Buku - Buku}

\section{DAFTAR PUSTAKA}

A.Mukthie Fadjar, PEMILU perselisihan hasil pemilu dan demokrasi, Setara Press,Jawa Timur, 2012

Burhan, Ahshofa. Metode Penelitian Hukum. PT. Rineka Cipta, Jakarta. 2010.

Bahder Johan Nasution. Moral Perlindungan Hak Asasi Manusia, Jurnal Konstitusi, Volume IV No. 1. 2011.

Buheti, kontrol Normatif dan Kedaulatan Rakyat: kajian makna demokrasi nomokoratif dalam praktik judicial review, Jurnal Konstitusi, Volume II No. 1.2013

Ibramsyah Amirudin, Kedudukan KPU Dalam Struktur Ketatanegaraan Republik Indonesia Pasca Amandemen UUD 1945 EDISI I CETAKAN I, Laksbang Mediatama, Yogyakarta, 2008.

Komisi Pemilihan Umum Kabupaten Merangin, Rekapitulasi Penghitungan Suara Pemilihan Umum Anggota DPR, DPD, DPRD Kabupaten Merangin Tahun 2014, Bangko, 2014.

Buku Laporan Penyelenggaraan Pemilihan Umum Anggota DPR, DPD, DPRD Kabupaten Merangin Tahun 2014, Bangko, 2014.

Miriam Budiarjo, Dasar-Dasar IlmuPolitik,edisi revisi,Cet IV, Pt Ikar Mandiri Abadi, Jakarta , 2010.
Muliansyah, Abdurahman, Demokrasi Untuk Siapa, Inti Media, Jawa Timur 2012.

Rozali Abdullah. Sistem Pemilu Legislatif dan Pemilu Presiden Ditinjau dari Sudut Pandang Demokrasi, Jurnal Konstitusi, Volume II No. 1. 2009.

Saiful Arif dan Heri Setiyono, Sejarah \& Budaya Demokrasi, Manusia Berstatus Dalam Kehidupan Bernegara Bangsa,Cet I, Averroes Press, Malang,2013.

Sodikin.Hukum Pemilu Sebagai Praktek Ketatanegaraan. Gramata Publising, Bekasi. 2014.

Tim Penyusun Kamus. Kamus Besar Bahasa Indonesia. Departemen Pendidikan Nasional, Jakarta. 2008.

\section{B. Peraturan Perundang-Undangan}

Republik Indonesia, Undang-Undang Dasar Negara Republik Indonesia Tahun 1945.

1956, Undang-Undang No. 12 Tahun 1956 Tentang Pembentukan Daerah Otonom Dalam Lingkungan Daerah Sumatra Tengah. Lembaran Negara RI Tahun 1956, No. 25 Menteri Dalam Negeri. Jakarta.

,2011, Undang-undang No. 15 tahun 2011 tentang penyelengaraan pemilihan umum.Lembaran Negara RI tahun 2011 Menteri Hukum dan Hak Asasi Manusia. Jakarta.

2012. Undang-Undang No. 8 Tahun 2012 tentang Pemilihan Umum Anggota Dewan Perwakilan Rakyat, Dewan Perwakilan Daerah, Dewan Perwakilan Rakyat Daerah.Lembaran Negara RI Tahun 2012, No. 117. Sekretariat Negara. Jakarta. 
2013, Peraturan Komisi Pemilihan Umum Nomor. 9 Tahun 2013 Tentang Penyusunan Daftar Pemilih Untuk Pemilihan Umum Anggota DPR, DPD, DPRD. Berita
Negara Republik Indonesia Tahun 2013.Nomor.407. Menteri Hukum dan Hak Asasi Manusia.jakarta 